\title{
Practical Considerations for the Nonvitamin K Antagonist Oral Anticoagulants
}

\author{
Rahul Trikha ${ }^{a}$ Peter R. Kowey ${ }^{a, b}$

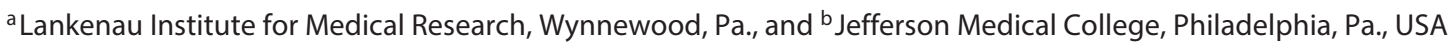

\section{Key Words}

Anticoagulants · Atrial fibrillation · Nonvitamin K ·

Treatment recommendations - Vitamin $\mathrm{K}$

\begin{abstract}
Objectives: Dabigatran, rivaroxaban, apixaban, and edoxaban are nonvitamin $\mathrm{K}$ antagonist oral anticoagulants (NOACs) approved for stroke prevention in patients with nonvalvular atrial fibrillation (NVAF). Phase-3 clinical trials demonstrated NOACs were as effective as warfarin in the prevention of stroke or systemic embolism and associated with decreased incidences of intracranial bleeding. Additionally, NOACs provide quicker onset of action, simpler dosing, more predictable pharmacokinetic profiles, and decreased food and drug interactions compared with warfarin. Despite the advantages of NOACs, the lack of knowledge may limit their use in clinical practice. Methods: A search was performed on the terms 'atrial fibrillation' and 'dabigatran', 'apixaban', 'edoxaban', or 'rivaroxaban' to identify relevant papers; large randomized clinical trials, meta-analyses, and treatment guideline recommendations were given preference. Searches to identify registries, treatment guidelines, and meta-analyses relevant to patient subgroups were also employed. Results: Dosing recommendations, initiation of treatment, and applications in patients who undergo NVAF
\end{abstract}

procedures, have mechanical heart valves, or experience other cardiovascular conditions such as myocardial infarction, previous stroke, and valvular heart disease are summarized. The NOAC-specific reversal approaches are also discussed. Conclusions: Several important factors should be considered regarding the adequate use of NOACs, especially in patients with renal impairment or cardiovascular conditions other than NVAF.

(c) 2016 S. Karger AG, Basel

\section{Introduction}

Approximately 5 years have passed since the introduction of the first nonvitamin $\mathrm{K}$ antagonist oral anticoagulant (NOAC) in the United States. Four NOACs - dabigatran, rivaroxaban, apixaban, and edoxaban - are available for the treatment of deep venous thrombosis and pulmonary embolism and for reducing the risk of stroke and systemic embolic events (SEE) in patients with nonvalvular atrial fibrillation (NVAF) [1-4]. These agents offer a number of advantages over traditional therapies, such as quicker onset of action, simpler dosing, more predictable pharmacokinetic profiles, and fewer food and drug interactions [5]. However, a lack of knowledge regarding NOACs among health care providers may limit

\section{KARGER}

(c) 2016 S. Karger AG, Basel

E-Mail karger@karger.com

www.karger.com/crd
Rahul Trikha

Lankenau Institute for Medical Research, Medical Office Building East, Suite 558 100 East Lancaster Avenue

Wynnewood, PA 19096 (USA)

E-Mail trikhar@mlhs.org 
their adoption in clinical practice. To this end, familiarizing clinicians with NOACs may facilitate their use and maximize their benefits to the patients.

Four major clinical trials were conducted to evaluate the use of NOACs for the reduction in stroke and SEE in NVAF: the RE-LY (Randomized Evaluation of LongTerm Anticoagulation Therapy), ROCKET-AF (Rivaroxaban Once Daily Oral Direct Factor Xa Inhibition Compared with Vitamin K Antagonism for Prevention of Stroke and Embolism Trial in Atrial Fibrillation), ARISTOTLE (Apixaban for Reduction in Stroke and Other Thromboembolic Events in Atrial Fibrillation), and ENGAGE AF-TIMI 48 (The Effective Anticoagulation with Factor Xa Next Generation in Atrial FibrillationThrombolysis in Myocardial Infarction 48) [6-9]. These trials demonstrated noninferiority or superiority of the NOACs in comparison with warfarin for the reduction in the risk of stroke or SEE [6-9]. This article reviews some of the management challenges faced by clinicians in the use of NOACs and addresses questions not definitively answered by the registration trials.

\section{Overall Bleeding Risk}

Anticoagulation is associated with an increased risk of bleeding [10]. Patients' 1-year bleeding risks can be assessed using the HAS-BLED score [hypertension, abnormal renal and liver function, stroke, bleeding history or predisposition, labile INR (international normalized ratio), elderly, drugs, or alcohol concomitantly); risk stratification using this tool is recommended by European but not US guidelines [11-13]. It is important to note that bleeding scores should not be used to contraindicate NOAC use, but to help the physician understand the risk and perhaps even optimize the bleeding risk. In ARISTOTLE, patients who experienced a major bleed tended to be older and had a history of myocardial infarction (MI), prior hemorrhage, impaired renal function, and a fall relative to patients who did not have a major bleed [14]. Bleeding risk for patients receiving warfarin varies greatly based on individual INR results, with the risk increasing once INR levels exceed 4 [15].

Compared with warfarin, in phase- 3 clinical trials, the NOACs were associated with similar or lower rates of major bleeding and significantly decreased rates of intracranial bleeding [6-9]. While the results of a meta-analysis reported that NOACs reduced intracranial bleeding [relative risk $(\mathrm{RR})=0.48,95 \%$ confidence interval $(\mathrm{CI}) 0.39$ $0.59, \mathrm{p}<0.0001$ ], RR for gastrointestinal (GI) bleeding was increased for the NOACs relative to warfarin $(\mathrm{RR}=$ $1.25,95 \%$ CI 1.01-1.55, $\mathrm{p}=0.043$ ) [16]. Rates of GI bleeding were higher for dabigatran, rivaroxaban, and edoxaban in the phase- 3 trials, although there was no difference in the rate of GI bleeding for apixaban relative to warfarin [6-9]. In one meta-analysis, although NOACs were at least as effective as warfarin in individuals $\geq 75$ years of age, elderly patients receiving dabigatran displayed an elevated risk of GI bleeding relative to warfarin [17]. The increased risk of GI bleeding in patients who received dabigatran was highly associated with increased age, renal impairment, heart failure, alcohol abuse, Helicobacter pylori infection, antiplatelet therapy, and digoxin use [18]. Table 1 summarizes bleeding risks including major, intracranial, and gastrointestinal bleeding.

\section{Dosing and Treatment Initiation}

For reducing the risk of stroke or SEE in patients with NVAF, the standard approved NOAC doses are dabigatran $150 \mathrm{mg}$ twice daily, apixaban $5 \mathrm{mg}$ twice daily, edoxaban $60 \mathrm{mg}$ once daily, and rivaroxaban $20 \mathrm{mg}$ once daily with the evening meal [1-4]. In the US, edoxaban is not approved for use in patients with a creatinine clearance $(\mathrm{CrCl})>95 \mathrm{ml} / \mathrm{min}$ [4]. Dosing adjustments may be required based on other considerations, including renal function and drug-drug interactions (table 2).

Although NOACs are generally associated with fewer drug-drug interactions than warfarin, clinicians should take precautions in prescribing NOACs with certain medications (table 3). All NOACs are substrates of P-glycoprotein (P-gp), and, with the exception of dabigatran, are metabolized to some extent by cytochrome $\mathrm{P}_{450} 3 \mathrm{~A} 4$ (CYP3A4) [1-4]. Thus, P-gp or CYP3A4 inducers may decrease NOAC exposure and effectiveness and P-gp or CYP3A4 inhibitors may increase NOAC exposure and elevate bleeding risks [1-4]. The NOACs should not be used with the strong P-gp/CYP3A4 inducer rifampin [14]. Coadministration of rivaroxaban and apixaban with the strong P-gp/CYP3A4 dual inducers carbamazepine, phenytoin, and St. John's wort should be avoided [2, 3]. The use of strong P-gp/CYP3A4 inhibitors such as ketoconazole and ritonavir should be avoided by patients taking rivaroxaban; a dose reduction for dabigatran and apixaban may be necessary [19]. No dose adjustment is recommended for the concomitant use of NOACs with less potent $\mathrm{P}-\mathrm{gp} / \mathrm{CYP} 3 \mathrm{~A} 4$ inhibitors such as amiodarone, diltiazem, and verapamil [19]. There is no recommendation for a dose reduction in edoxaban with dual P-gp/ 
Table 1. Bleeding outcomes in the phase-3 clinical trials [6-9]

\begin{tabular}{|c|c|c|c|c|c|c|c|c|c|c|}
\hline \multirow{2}{*}{$\begin{array}{l}\text { Bleeding } \\
\text { type }\end{array}$} & \multicolumn{3}{|l|}{ RE-LY [6] } & \multicolumn{2}{|c|}{ ROCKET-AF [9] } & \multicolumn{2}{|c|}{ ARISTOTLE [8] } & \multicolumn{3}{|c|}{ ENGAGE AF-TIMI 48 [7] } \\
\hline & $\begin{array}{l}\text { dabigatran } \\
150 \mathrm{mg} \\
\mathrm{n}=6,076\end{array}$ & $\begin{array}{l}\text { dabigatran } \\
110 \mathrm{mg} \\
\mathrm{n}=6,015\end{array}$ & $\begin{array}{l}\text { warf. } \\
n= \\
6,022\end{array}$ & $\begin{array}{l}\text { rivaroxaban } \\
20 \mathrm{mg} \\
\mathrm{n}=7,111\end{array}$ & $\begin{array}{l}\text { warf. } \\
\mathrm{n}=7125\end{array}$ & $\begin{array}{l}\text { apixaban } \\
5 \mathrm{mg} \\
\mathrm{n}=9,088\end{array}$ & $\begin{array}{l}\text { warf. } \\
n=9,052\end{array}$ & $\begin{array}{l}\text { edoxaban } \\
60 \mathrm{mg} \\
\mathrm{n}=7,012\end{array}$ & $\begin{array}{l}\text { edoxaban } \\
30 \mathrm{mg} \\
\mathrm{n}=7,002\end{array}$ & $\begin{array}{l}\text { warf. } \\
\mathrm{n}= \\
7,012\end{array}$ \\
\hline \multicolumn{11}{|c|}{ Major bleeding } \\
\hline$\%$ & 3.11 & 2.71 & 3.36 & 5.60 & 5.40 & 2.13 & 3.09 & 2.75 & 1.61 & 3.43 \\
\hline $\mathrm{n}$ & 375 & 322 & 397 & 395 & 386 & 327 & 462 & 418 & 254 & 524 \\
\hline $\mathrm{HR}$ & 0.93 & 0.80 & - & 1.04 & - & 0.69 & - & 0.80 & 0.47 & - \\
\hline $95 \% \mathrm{CI}$ & $0.81-1.07$ & $0.69-0.93$ & & $0.90-1.20$ & & $0.60-0.80$ & & $0.71-0.91$ & $0.41-0.55$ & \\
\hline $\mathrm{p}$ value & 0.31 & 0.003 & - & 0.58 & - & $<0.001$ & - & $<0.001$ & $<0.001$ & - \\
\hline \multicolumn{11}{|c|}{ Intracranial bleeding } \\
\hline$\%$ & 0.30 & 0.23 & 0.74 & 0.80 & 1.20 & 0.33 & 0.80 & 0.39 & 0.26 & 0.85 \\
\hline $\mathrm{n}$ & 36 & 27 & 87 & 55 & 84 & 52 & 122 & 61 & 41 & 132 \\
\hline $\mathrm{HR}$ & 0.40 & 0.31 & - & 0.67 & - & 0.42 & - & 0.47 & 0.30 & - \\
\hline $95 \%$ CI & $0.27-0.60$ & $0.20-0.47$ & & $0.47-0.93$ & & $0.30-0.58$ & & $0.34-0.63$ & $0.21-0.43$ & \\
\hline $\mathrm{p}$ value & $<0.001$ & $<0.001$ & - & 0.02 & - & $<0.001$ & - & $<0.001$ & $<0.001$ & - \\
\hline \multicolumn{11}{|c|}{ GI bleeding } \\
\hline$\%$ & 1.51 & 1.12 & 1.02 & 3.15 & 2.16 & 0.76 & 0.86 & 1.51 & 0.82 & 1.23 \\
\hline $\mathrm{n}$ & 182 & 133 & 120 & 224 & 154 & 105 & 119 & 232 & 129 & 190 \\
\hline $\mathrm{HR}$ & 1.50 & 1.10 & - & NR & - & 0.89 & - & 1.23 & 0.67 & - \\
\hline $95 \% \mathrm{CI}$ & $1.19-1.89$ & $0.86-1.41$ & & & & $0.70-1.15$ & & $1.02-1.50$ & $0.53-0.83$ & \\
\hline $\mathrm{p}$ value & $<0.001$ & 0.43 & - & $<0.001$ & - & 0.37 & - & 0.03 & $<0.001$ & - \\
\hline
\end{tabular}

$\mathrm{HR}<1$ indicate less bleeding with the active drug relative to warfarin (warf.). NR = Not reported.

CYP3A4 inhibitors [4]. Additionally, coadministration of most NOACs with other anticoagulants, nonsteroidal anti-inflammatory drugs, aspirin, or antiplatelet medications increases the bleeding risk [1-4]. Patients undergoing concomitant treatment with NOACs and these agents should be closely monitored for symptoms of bleeding or blood loss [1-4]. In a study in which patients received single antiplatelet treatment, primarily aspirin, in combination with edoxaban, patients receiving edoxaban and antiplatelet therapy had higher rates of major bleeding [hazard ratio (HR) 1.46, 95\% CI 1.27-1.67, $\mathrm{p}<0.001$ ] relative to those receiving edoxaban alone, with no difference in the rate of stroke or SEE (HR 1.12, 95\% CI 0.951.32) [20].

To switch from warfarin to a NOAC, patients should have an INR $<2$ for dabigatran or apixaban, $<3$ for rivaroxaban, and $<2.5$ for edoxaban in order to avoid periods of inadequate anticoagulation [1-4]. Patients transitioning from dabigatran to warfarin should initiate warfarin treatment while still taking dabigatran; the period of treatment overlap should be adjusted based on renal function, with longer overlap periods for higher $\mathrm{CrCl}$ values [1]. Warfarin should be started 3 days before discontinuing dabigatran for a $\mathrm{CrCl} \geq 50 \mathrm{ml} / \mathrm{min}, 2$ days before discontinuation for $\mathrm{CrCl} 30-50 \mathrm{ml} / \mathrm{min}$, and 1 day before discontinuation for $\mathrm{CrCl} 15-30 \mathrm{ml} / \mathrm{min}$. No recommendations are available for patients with a $\mathrm{CrCl}<15 \mathrm{ml} / \mathrm{min}$ [1]. Patients switching from rivaroxaban, apixaban, or edoxaban to warfarin should discontinue the NOAC and initiate a parenteral anticoagulant along with warfarin at the time of the next NOAC dose; the parenteral anticoagulant may be discontinued when INR reaches an acceptable range [2-4]. Patients receiving edoxaban may also reduce their edoxaban dose by half when starting warfarin and discontinue edoxaban once a stable INR $\geq 2.0$ is achieved [4]. Switching between NOACs or to anticoagulants other than warfarin can generally be performed by administering the first dose at the normally scheduled time of the NOAC [1-4].

\section{Renal Impairment}

In patients with NVAF, renal impairment increases the risk for both cardiovascular events and bleeding. The NOACs exhibit varying rates of renal excretion of the absorbed dose (i.e. renal clearance is $80 \%$ for dabigatran, $66 \%$ for rivaroxaban, approximately $50 \%$ for edoxaban, and $27 \%$ for apixaban) [1-4]; therefore, an assessment of renal function prior to initiation of NOACs, and periodi- 
Table 2. Patient dosing considerations for NVAF [1-4]

\begin{tabular}{|c|c|c|c|c|}
\hline $\begin{array}{l}\text { Patient } \\
\text { population }\end{array}$ & $\begin{array}{l}\text { Dabigatran } \\
150 \mathrm{mg}\end{array}$ & $\begin{array}{l}\text { Rivaroxaban } \\
20 \mathrm{mg}\end{array}$ & $\begin{array}{l}\text { Apixaban } \\
5 \mathrm{mg}\end{array}$ & $\begin{array}{l}\text { Edoxaban }^{\mathrm{a}} \\
60 \mathrm{mg}\end{array}$ \\
\hline $\begin{array}{l}\text { Renal } \\
\text { impairment }\end{array}$ & $\begin{array}{l}\text { Reduce dose to } 75 \mathrm{mg} \\
\text { b.i.d. if } \mathrm{CrCl} 15-30 \mathrm{ml} / \\
\mathrm{min} \\
\text { Avoid use for } \mathrm{CrCl}<30 \\
\mathrm{ml} / \mathrm{min} \text { and concomitant } \\
\mathrm{P} \text {-gp inhibitors } \\
\text { No recommendations } \\
\text { if } \mathrm{CrCl} \leq 15 \mathrm{ml} / \mathrm{min} \text { or } \\
\text { on dialysis }\end{array}$ & $\begin{array}{l}\text { No dose adjustment for } \\
\mathrm{CrCl}>50 \mathrm{ml} / \mathrm{min} \\
\text { Reduce dose to } 15 \mathrm{mg} \\
\text { once daily with the } \\
\text { evening meal for } \\
\mathrm{CrCl} 15-50 \mathrm{ml} / \mathrm{min} \\
\text { Avoid if } \mathrm{CrCl}<30 \mathrm{ml} / \\
\text { min }\end{array}$ & $\begin{array}{l}\text { Serum creatinine } \geq 1.5 \mathrm{mg} / \mathrm{dl} \\
\text { and body weight } \leq 60 \mathrm{~kg} \text { or } \\
\text { age } \geq 80 \text { years: reduce dose } \\
\text { to } 2.5 \mathrm{mg} \text { b.i.d. }\end{array}$ & $\begin{array}{l}\text { Reduce dose to } 30 \mathrm{mg} \\
\text { once daily if } \mathrm{CrCl} \text { is } \\
15-50 \mathrm{ml} / \mathrm{min} \\
\mathrm{CrCl}<15 \mathrm{ml} / \mathrm{min} \text { : not } \\
\text { recommended }\end{array}$ \\
\hline Elderly & No dose adjustment & No dose adjustment & $\begin{array}{l}\text { Age } \geq 80 \text { years and body } \\
\text { weight } \leq 60 \mathrm{~kg} \text { or serum } \\
\text { creatinine } \geq 1.5 \mathrm{mg} / \mathrm{dl} \text { : } \\
\text { reduce dose to } 2.5 \mathrm{mg} \text { b.i.d. }\end{array}$ & No dose adjustment \\
\hline Hepatic & $\begin{array}{l}\text { Moderate hepatic } \\
\text { impairment } \\
\text { (Child-Pugh B): no } \\
\text { dosing adjustment }\end{array}$ & $\begin{array}{l}\text { Avoid use in patients } \\
\text { with moderate } \\
\text { (Child-Pugh B) and } \\
\text { severe (Child-Pugh C) } \\
\text { hepatic impairment, } \\
\text { or any hepatic disease } \\
\text { associated with } \\
\text { coagulopathy }\end{array}$ & $\begin{array}{l}\text { No dose reduction for mild } \\
\text { hepatic impairment } \\
\text { (Child-Pugh A) } \\
\text { Moderate hepatic } \\
\text { impairment (Child-Pugh B): } \\
\text { no dosing recommendations } \\
\text { provided } \\
\text { Severe hepatic impairment } \\
\text { (Child-Pugh C): not } \\
\text { recommended }\end{array}$ & $\begin{array}{l}\text { Mild hepatic impairment } \\
\text { (Child-Pugh A): no dose } \\
\text { reduction required } \\
\text { Moderate (Child-Pugh B) } \\
\text { and severe (Child-Pugh C) } \\
\text { hepatic impairment: not } \\
\text { recommended }\end{array}$ \\
\hline
\end{tabular}

${ }^{\text {a }}$ Do not use edoxaban in patients with $\mathrm{CrCl}>95 \mathrm{ml} / \mathrm{min}$ in the US.

cally thereafter, is recommended at the discretion of the physician $[1,2,13]$. In patients with mild-to-moderate renal impairment $(\mathrm{CrCl}=30$ to $<80 \mathrm{ml} / \mathrm{min})$, dabigatran exposure, based on the area under the plasma concentration-time curve, was reported to be 1.5-3.2 times that of patients with a normal $\mathrm{CrCl}(\geq 80 \mathrm{ml} / \mathrm{min})$ [1]. Dabigatran should be adjusted to a dose of $75 \mathrm{mg}$ twice daily for patients with severe renal impairment $(\mathrm{CrCl}=15-30 \mathrm{ml} /$ min) and for patients with moderate renal impairment $(30-50 \mathrm{ml} / \mathrm{min})$ who are also taking dronedarone or systemic ketoconazole (see table 2 for dosing recommendations in the US). The use of dabigatran and concomitant $\mathrm{P}$-gp inhibitors should be avoided in patients with a $\mathrm{CrCl}$ of $15-30 \mathrm{ml} / \mathrm{min}$. No dosing recommendations are provided for patients with $\mathrm{CrCl}<15 \mathrm{ml} / \mathrm{min}$. Rivaroxaban should be administered as a once-daily 15-mg dose with the evening meal in patients with a $\mathrm{CrCl}$ of $15-50 \mathrm{ml} / \mathrm{min}$ [2]. There were no significant differences between riva- roxaban- (15 mg daily) and warfarin-treated patients for the outcome of stroke or SEE, major bleeding, or intracranial hemorrhage in a subanalysis of patients with moderate renal impairment $(\mathrm{CrCl}, 30-49 \mathrm{ml} / \mathrm{min})$ from the ROCKET-AF trial [21]. Further analysis of the ROCKET-AF trial revealed that, in patients with worsening renal function ( $\geq 20 \%$ decrease from screening $\mathrm{CrCl}$ ), rivaroxaban was associated with lower rates of stroke or SEE than warfarin, with a similar risk of bleeding [22].

A reduced dose of apixaban ( $2.5 \mathrm{mg}$ twice daily) is recommended for patients meeting 2 of the following criteria: serum creatinine level $\geq 1.5 \mathrm{mg} / \mathrm{dl}$, age $\geq 80$ years, or body weight $\leq 60 \mathrm{~kg}$ [3]. Recently, full-dose apixaban was approved in patients with end-stage renal disease (ESRD; $\mathrm{CrCl}<15 \mathrm{ml} / \mathrm{min}$ ) [3]. This is the first NOAC approved for use in patients with ESRD; however, it should be noted that patients with ESRD were not included in clinical efficacy and safety studies and that dosing recommenda- 
Table 3. Drug-drug interactions [1-4]

\begin{tabular}{|c|c|c|}
\hline Drug & Dual P-gp/CYP3A4 inhibitors & Dual P-gp/CYP3A4 inducers \\
\hline Dabigatran & $\begin{array}{l}\text { Reduce } 75 \mathrm{mg} \text { b.i.d. dose for patients with moderate renal impairment } \\
(\mathrm{CrCl} 30-50 \mathrm{ml} / \mathrm{min}) \text { with ketoconazole, dronedarone } \\
\text { No dose adjustment required for clarithromycin, amiodarone, } \\
\text { quinidine, verapamil, ticagrelor }\end{array}$ & Avoid coadministration with rifampin \\
\hline Rivaroxaban & $\begin{array}{l}\text { Avoid use with P-gp and strong CYP3A4 inhibitors } \\
\text { (ketoconazole, itraconazole, lopinavir, ritonavir, indinavir, } \\
\text { conivaptan) }\end{array}$ & $\begin{array}{l}\text { Avoid strong dual inducers of P-gp and } \\
\text { CYP3A4 carbamazepine, phenytoin, } \\
\text { rifampin, St. John's wort }\end{array}$ \\
\hline Apixaban & $\begin{array}{l}\text { A } 50 \% \text { dose reduction is recommended for patients receiving a dose } \\
>2.5 \mathrm{mg} \text { b.i.d. when coadministered with strong dual inhibitors of } \\
\text { CYP3A4 and P-gp (ketoconazole, itraconazole, ritonavir, or } \\
\text { clarithromycin); avoid use of these drugs when dosage is } 2.5 \mathrm{mg} \text {, b.i.d. }\end{array}$ & $\begin{array}{l}\text { Avoid strong dual inducers of P-gp and } \\
\text { CYP3A4 carbamazepine, phenytoin, } \\
\text { rifampin, St. John's wort }\end{array}$ \\
\hline Edoxaban & No dose reduction & Avoid concomitant use of rifampin \\
\hline
\end{tabular}

tions are based on pharmacokinetic and pharmacodynamic data in subjects with ESRD who were maintained on dialysis [3].

Edoxaban should be given at a reduced dose of $30 \mathrm{mg}$ to patients with a $\mathrm{CrCl}$ of $15-50 \mathrm{ml} / \mathrm{min}$ [4]. Limited clinical data support the use of edoxaban in patients with $\mathrm{CrCl}<15 \mathrm{ml} / \mathrm{min}$, and its use is not recommended in this population [4].

\section{Patients}

Each of the phase-3 clinical trials included patients with a history of MI [6-9]. In these phase-3 trials, there were no differences in safety between treatment with warfarin and 30 or $60 \mathrm{mg}$ of edoxaban, or between rivaroxaban and warfarin in patients with prior MI; no subgroup analysis for prior MI was reported for apixaban [6-9].

Although reports are conflicting, some evidence supports a possible association of dabigatran with MI. In the initial analysis of the dabigatran NVAF phase-3 trial, dabigatran $150 \mathrm{mg}$ was associated with increased rates of MI (0.74 vs. $0.53 \%$ per year, RR $1.38,95 \%$ CI $1.00-1.91, \mathrm{p}=$ 0.048 ) compared to warfarin [6]. However, the rates of MI for dabigatran $150 \mathrm{mg}$ versus warfarin were revised to 0.81 versus $0.64 \%$ per year (RR $1.27,95 \%$ CI $0.94-1.71$, $\mathrm{p}=0.12$ ) following reevaluation of the database for possible event underreporting in 2010 [23]. In a meta-analysis including 14 randomized controlled trials of dabigatran, the 150-mg dose of dabigatran was associated with increased odds of MI $(1.43,95 \%$ CI $1.08-1.89, \mathrm{p}=0.014)$ compared to warfarin [24]. Similarly, the results from a meta-analysis of the phase-3 NVAF trials for all 4 NOACs reported a significant increase in MI with dabigatran [25]. Notably, compared to the rest of the phase-3 RE-LY trial population, patients who had at least $1 \mathrm{MI}$ were older and had more coronary risk factors [26]. Although the exact mechanism underlying the possible association of dabigatran with $\mathrm{MI}$ is unclear, one theory suggests that the direct inhibition of thrombin may result in procoagulant activity, as thrombin has been shown to have both procoagulant and anticoagulant effects [27]. Alternately, this may reflect the benefit of warfarin.

The use of NOACs is not supported for patients with acute coronary syndrome (ACS). In the APPRAISE-2 (Apixaban for Prevention of Acute Ischemic Events 2) trial, increased bleeding in patients treated with apixaban, aspirin, and clopidogrel compared to those treated with placebo led to early study termination [28]. Dose-dependent increases in bleeding versus placebo were also observed in a phase-2 study, RE-DEEM (Randomized Dabigatran Etexilate Dose-Finding Study in Patients with Acute Coronary Syndromes), following treatment of ACS patients with dabigatran in combination with clopidogrel and aspirin [29]. A reduction in rates of the composite of cardiovascular death, MI, and stroke in patients treated with rivaroxaban and dual antiplatelet therapy was demonstrated in the ATLAS ACS 2-TIMI 51 (Anti-Xa Therapy to Lower Cardiovascular Events in Addition to Standard Therapy in Subjects with Acute Coronary Syndrome-Thrombolysis in Myocardial Infarction 51) trial [30]. However, both clinical and statistical reviewers of the US Food and Drug Administration expressed concerns over high rates of missing data [31]. The efficacy and safety of NOACs as treatment strategies for these patients remains unresolved. 


\section{Patients Undergoing Atrial Fibrillation Procedures}

For patients in whom a rhythm control strategy (restoration and maintenance of sinus rhythm) is attempted, the incidence of stroke is highest within 30 days of cardioversion, whether by electrical, pharmacologic, or ablative methods [32]. While the data for use of the NOACs in this population are limited, post hoc analyses of the phase-3 trials provided some insights. Patients receiving dabigatran in the RE-LY trial demonstrated comparable rates of stroke and major bleeding to those receiving warfarin within 30 days of cardioversion [33]. Analysis of the ROCKET-AF trial showed no significant difference in long-term stroke rates or survival following cardioversion or ablation between patients treated with rivaroxaban and warfarin [34]. In the ARISTOTLE trial, major cardiovascular events after cardioversion were comparable between patients receiving apixaban and warfarin [35]. These findings are supported by a meta-analysis of 4 randomized controlled trials for NOACs that concludes that NOACs are at least as effective and safe as vitamin $\mathrm{K}$ antagonists (VKA) for NVAF patients undergoing cardioversion procedures [36]. The use of edoxaban for cardioversion is under evaluation in an ongoing prospective clinical trial [Edoxaban vs. Warfarin in Subjects Undergoing Cardioversion of Atrial Fibrillation (ENSURE-AF) Study, clintrials.gov NCT02072434] [37].

The X-VeRT prospective randomized trial (Explore the Efficacy and Safety of Once-Daily Oral Rivaroxaban for the Prevention of Cardiovascular Events in Patients with Nonvalvular Atrial Fibrillation Scheduled for Cardioversion) was the first completed trial of a NOAC in patients with atrial fibrillation undergoing elective cardioversion [38]. Patients were randomized to receive rivaroxaban or VKA therapy for either a duration ranging from 1 to 5 days of treatment prior to cardioversion or 3-8 weeks prior to cardioversion. In patients with delayed cardioversion, adequate VKA treatment required an INR in the range of 2.0-3.0 for at least 3 consecutive weeks prior to cardioversion [38]. Compared with VKA therapy, rivaroxaban was associated with similar rates of stroke/other cardiovascular events and bleeding, but a significantly shorter time to cardioversion. The X-VeRT trial showed that rivaroxaban is a safe and effective alternative to warfarin in patients undergoing elective electrical cardioversion. In addition, in a cohort study comparing the efficacy and safety between dabigatran and warfarin in NVAF patients undergoing cardioversion, dabigatran demonstrated similar risks of adverse events and NVAF readmission relative to warfarin, but the time to cardioversion was shorter for dabigatran [39]. Both studies indicate that NOACs may even allow for more prompt cardioversion. Several other trials are ongoing that are studying the other NOACs with regard to elective cardioversion and ablation.

\section{Patients with Previous Stroke or Transient Ischemic Attack}

Subgroup analyses of the phase-3 clinical trials provided insights into the use of NOACs in NVAF patients with prior stroke or transient ischemic attack (TIA). In general, patients with a previous stroke/TIA displayed higher rates of stroke or SEE than those without across all trials [6-9]. Formal subgroup analyses indicated that the use of dabigatran, rivaroxaban, and apixaban in patients with and without previous stroke or TIA resulted in similar efficacy and safety [40-42]. In a meta-analysis of dabigatran, rivaroxaban, and apixaban, NOACs were as effective as warfarin in preventing stroke or SEE in patients with prior stroke/TIA with a decreased rate of intracranial bleeding; indirect comparison of any 2 of the NOACs showed similar efficacy [43]. Although no subanalysis has been performed for edoxaban, prespecified analyses showed consistent efficacy and safety regardless of patients' stroke/TIA history [7].

\section{Patients with Mechanical Heart Valves}

Dabigatran is the only NOAC investigated in clinical trials in patients with mechanical heart valves. The phase-2 dose validation study RE-ALIGN (Randomized Phase II Study to Evaluate the Safety and Pharmacokinetics of Oral Dabigatran Etexilate in Patients after Heart Valve Replacement) was terminated early due to excess thromboembolic and bleeding events in patients randomized to dabigatran, which was not found to be an appropriate alternative to warfarin [44]. Of the patients receiving dabigatran, $5 \%$ experienced a stroke and $2 \%$ had an MI (2\%), whereas no cases of stroke or MI were reported for patients receiving warfarin; an additional 3\% of dabigatran patients had valve thrombosis without clinical symptoms [44]. Major bleeding occurred in $4 \%$ of dabigatran patients and $2 \%$ of the warfarin patients; bleeding of any type occurred in $27 \%$ of dabigatran patients and $12 \%$ of warfarin patients [44]. No NOAC is approved for use in patients with mechanical heart valves or bioprosthetic valves. 


\section{Patients with Valvular Heart Disease}

The NOACs are approved for use in patients with NVAF, defined as atrial fibrillation without rheumatic mitral stenosis. They are not approved for patients with mechanical heart valves. Some data suggest NOACs may be used in patients with bioprosthetic heart valves. Yadlapati et al. [45] conducted a single-center, cohort study in 73 patients with bioprosthetic valves who received dabigatran, rivaroxaban, or apixaban. Data suggest that NOACs appear safe and effective in patients with regard to thromboembolic events but may increase bleeding. However, larger studies should be performed for confirmation. The phase-2 RE-ALIGN trial, designed to evaluate the safety of dabigatran versus warfarin in patients with mechanical heart valves, was stopped prematurely due to significant bleeding in the dabigatran-treated group [44]. Mild mitral stenosis was not an exclusion criterion in either the edoxaban or apixaban phase- 3 clinical trials $[7,8]$. A subgroup analysis of patients enrolled in the apixaban phase- 3 trial with other valvular disease was recently published. This analysis reported no differential effect between apixaban and warfarin in preventing stroke or SEE, causing bleeding, or reducing death in patients with and without valvular heart disease [46].

\section{Reversal Agents}

One of the major concerns for use of the NOACs has been the lack of a reversal agent. These concerns exist despite evidence that NOACs are associated with less intracranial hemorrhage and fatal hemorrhage compared with warfarin in large randomized clinical trials. Idarucizumab, a human antibody fragment, is the only approved NOAC antidote for the reversal of dabigatran when bleeding cannot be controlled [47]. This agent acts through binding free and thrombin-bound dabigatran with high affinity and neutralizing its activity [48]. In a phase-3 clinical trial, idarucizumab almost completely neutralized the anticoagulant effect of dabigatran in patients who experienced serious bleeding or required an urgent procedure [48]. Several other reversal agents are in development for NOACs. Andexanet alfa (PRT064445; Portola Pharmaceuticals, Inc., South San Francisco, Calif., USA), a recombinant catalytically inactive factor Xa decoy molecule, has been shown to rapidly reverse the effect of rivaroxaban and apixaban in phase- 2 and -3 clinical trials $[49,50]$ and to reverse edoxaban in phase- 2 clinical trials [51]. This agent is under regulatory review as a universal antidote for factor Xa inhibitors [52]. Ciraparantag (PER977; Perosphere, Inc., Danbury, Conn., USA), a synthetic small molecule that binds all 4 NOACs via hydrogen bonds, is in early-phase trials for the reversal of NOACs [49]. In a phase-1 study in healthy volunteers taking edoxaban, ciraparantag dose-dependently shortened the whole blood clotting time and restored normal clot architecture [49].

NOAC-specific guidelines recommend antidote administration in situations of 'life-threatening bleeding, bleeding into a critical organ or closed space, prolonged bleeding despite local hemostatic measures, high risk for recurrent bleeding because of NOAC overdose or delayed clearance, and urgent intervention associated with high bleeding risk' [49]. We suspect that their use will be limited. It is also important to understand that it will be hard to prove that they have a statistically significant effect on hard clinical endpoints. Their value may lie in changing physician and patient perspectives so that more high-risk patients will be amenable to using NOACs. Except for patients who experience life-threatening bleeding or require emergency surgery for life-threatening conditions, the decision to initiate NOAC antidotes should be guided by the time of the last NOAC dose, $\mathrm{CrCl}$ measurement, and laboratory tests for NOAC anticoagulant effects or plasma concentrations [49]. It should be noted that these laboratory tests may not be readily available. In addition to NOAC-specific antidotes, practice guidelines suggest that activated prothrombin complex concentrate and recombinant factor VIIa may be used as nonspecific reversal agents for NOACs [13], although clinical trial evidence of efficacy is lacking.

\section{Conclusions}

NOACs are at least as effective as warfarin in the prevention of stroke or SEE in patients with NVAF with improved safety, demonstrated by a decreased risk of intracranial hemorrhage compared with warfarin. Although NOACs offer significant advantages over warfarin, several important factors should be considered regarding the adequate use of these agents, especially in patients with renal impairment or cardiovascular conditions other than NVAF. Overall, appropriate use of NOACs requires following guidelines and prescribing instructions. Clinicians should take precautions in prescribing NOACs in conjunction with some medications as P-gp or CYP3A4 inducers, and inhibitors may affect NOAC exposure levels and bleeding risks. Coadministration of NOACs with 
nonsteroidal anti-inflammatory drugs, aspirin, or antiplatelet use increases the risk of bleeding. NOACs vary in dosing regimens and require dose adjustments in patients with compromised renal function based on specific criteria for each individual agent.

While NOACs have not been widely tested in atrial fibrillation patients with other cardiovascular conditions, subgroup analyses of the phase- 3 trial data provided some insights into this area. The efficacy and safety of NOACs as treatment strategies for patients with MI remain unresolved, although patients with ACS should not receive NOACs. Data regarding the use of NOACs in those undergoing procedures for atrial fibrillation and those with prior stroke or TIA are limited. The NOACs are not approved for use in patients with valvular heart disease, defined as rheumatic mitral stenosis, or patients with mechanical heart valves. More recently, some data may suggest they may be efficacious in patients with bioprosthetic heart valves; however, larger studies are need- ed to confirm this finding. The availability of specific antidotes will improve safety and facilitate the use of NOACs. Although clinicians using NOACs may be faced with some management challenges, NOACs are a safe and effective choice for the treatment of atrial fibrillation.

\section{Acknowledgments}

Writing and editorial support was provided by Terri Schochet, $\mathrm{PhD}$, and Liqing Xiao, $\mathrm{PhD}$, of AlphaBioCom, LLC, and funded by Daiichi Sankyo.

\section{Conflict of Interest}

Dr. Trikha reports no conflicts of interest. Dr. Kowey receives consulting fees from Johnson and Johnson, Boehringer Ingelheim, Pfizer, Daiichi Sankyo, Portola, and Merck. He does not hold any equity interest in any pharmaceutical company.

\section{References}

1 Pradaxa ${ }^{\circledR}$ (package insert): Pradaxa ${ }^{\circledR}$ (dabigatran etexilate mesylate) capsules for oral use. Full prescribing information. Ridgefield, Boehringer Ingelheim Pharmaceuticals, 2015.

2 Xarelto ${ }^{\circledR}$ (package insert): Xarelto ${ }^{\circledR}$ (rivaroxaban) tablets for oral use. Full prescribing information. Titusville, Janssen Pharmaceuticals, 2015.

3 Eliquis $^{\circledR}$ (package insert): Eliquis ${ }^{\circledR}$ (apixaban) tablets for oral use. Full prescribing information. Princeton, Bristol-Myers Squibb, 2015.

4 Savaysa $^{\mathrm{TM}}$ (package insert): Savaysa ${ }^{\mathrm{TM}}$ (edoxaban) tablets for oral use. Full prescribing information. Parsippany, Daiichi Sankyo, 2015.

5 Bauer KA: Pros and cons of new oral anticoagulants. Hematology Am Soc Hematol Educ Program 2013;2013:464-470.

6 Connolly SJ, Ezekowitz MD, Yusuf S, Eikelboom J, Oldgren J, Parekh A, Pogue J, Reilly PA, Themeles E, Varrone J, Wang S, Alings M, Xavier D, Zhu J, Diaz R, Lewis BS, Darius H, Diener HC, Joyner CD, Wallentin L; RELY Steering Committee Investigators: Dabigatran versus warfarin in patients with atrial fibrillation. N Engl J Med 2009;361:11391151.

7 Giugliano RP, Ruff CT, Braunwald E, Murphy SA, Wiviott SD, Halperin JL, Waldo AL, Ezekowitz MD, Weitz JI, Spinar J, Ruzyllo W, Ruda M, Koretsune Y, Betcher J, Shi M, Grip LT, Patel SP, Patel I, Hanyok JJ, Mercuri M, Antman EM; Engage AF-TIMI Investigators: Edoxaban versus warfarin in patients with atrial fibrillation. N Engl J Med 2013;369: 2093-2104.
8 Granger $\mathrm{CB}$, Alexander JH, McMurray JJ, Lopes RD, Hylek EM, Hanna M, Al-Khalidi HR, Ansell J, Atar D, Avezum A, Bahit MC, Diaz R, Easton JD, Ezekowitz JA, Flaker G, Garcia D, Geraldes M, Gersh BJ, Golitsyn S, Goto S, Hermosillo AG, Hohnloser SH, Horowitz J, Mohan P, Jansky P, Lewis BS, Lopez-Sendon JL, Pais P, Parkhomenko A, Verheugt FW, Zhu J, Wallentin L; Aristotle Committees Investigators: Apixaban versus warfarin in patients with atrial fibrillation. $\mathrm{N}$ Engl J Med 2011;365:981-992.

9 Patel MR, Mahaffey KW, Garg J, Pan G, Singer DE, Hacke W, Breithardt G, Halperin JL, Hankey GJ, Piccini JP, Becker RC, Nessel CC, Paolini JF, Berkowitz SD, Fox KAA, Califf RM: Rivaroxaban versus warfarin in nonvalvular atrial fibrillation. N Engl J Med 2011; 365:883-891.

10 Levine MN, Raskob G, Landefeld S, Kearon C: Hemorrhagic complications of anticoagulant treatment. Chest 2001;119:108S-121S.

11 Camm AJ, Lip GY, De Caterina R, Savelieva I, Atar D, Hohnloser SH, Hindricks G, Kirchhof P; ESC Committee for Practice Guidelines: 2012 focused update of the ESC Guidelines for the management of atrial fibrillation: an update of the 2010 ESC Guidelines for the management of atrial fibrillation. Developed with the special contribution of the European Heart Rhythm Association. Eur Heart J 2012; 33:2719-2747.
12 Heidbuchel H, Verhamme P, Alings M, Antz M, Hacke W, Oldgren J, Sinnaeve P, Camm AJ, Kirchhof P; European Heart Rhythm Association: European Heart Rhythm Association Practical Guide on the use of new oral anticoagulants in patients with non-valvular atrial fibrillation. Europace 2013;15:625-651.

13 January CT, Wann LS, Alpert JS, Calkins H, Cigarroa JE, Cleveland JC Jr, Conti JB, Ellinor PT, Ezekowitz MD, Field ME, Murray KT, Sacco RL, Stevenson WG, Tchou PJ, Tracy CM, Yancy CW; ACC/AHA Task Force Members: 2014 AHA/ACC/HRS guideline for the management of patients with atrial fibrillation: a report of the American College of Cardiology/American Heart Association Task Force on practice guidelines and the Heart Rhythm Society. Circulation 2014; 130:e199-e267.

14 Hylek EM, Held C, Alexander JH, Lopes RD, De Caterina R, Wojdyla DM, Huber K, Jansky P, Steg PG, Hanna M, Thomas L, Wallentin L, Granger CB: Major bleeding in patients with atrial fibrillation receiving apixaban or warfarin: the ARISTOTLE Trial (Apixaban for Reduction in Stroke and Other Thromboembolic Events in Atrial Fibrillation): predictors, characteristics, and clinical outcomes. J Am Coll Cardiol 2014;63:2141-2147.

15 Hirsh J, Fuster V, Ansell J, Halperin JL; American Heart Association/American College of Cardiology Foundation: American Heart Association/American College of Cardiology Foundation guide to warfarin therapy. J Am Coll Cardiol 2003;41:1633-1652. 
16 Ruff CT, Giugliano RP, Braunwald E, Hoffman EB, Deenadayalu N, Ezekowitz MD, Camm AJ, Weitz JI, Lewis BS, Parkhomenko A, Yamashita T, Antman EM: Comparison of the efficacy and safety of new oral anticoagulants with warfarin in patients with atrial fibrillation: a meta-analysis of randomised trials. Lancet 2014;383:955-962.

17 Sharma M, Cornelius VR, Patel JP, Davies JG, Molokhia M: Efficacy and harms of direct oral anticoagulants in the elderly for stroke prevention in atrial fibrillation and secondary prevention of venous thromboembolism: systematic review and meta-analysis. Circulation 2015;132:194-204.

18 Lauffenburger JC, Rhoney DH, Farley JF, Gehi AK, Fang G: Predictors of gastrointestinal bleeding among patients with atrial fibrillation after initiating dabigatran therapy. Pharmacotherapy 2015;35:560-568.

19 Maan A, Heist EK, Ruskin JN, Mansour M: Practical issues in the management of novel oral anticoagulants - cardioversion and ablation. J Thorac Dis 2015;7:115-131.

$20 \mathrm{Xu} \mathrm{H}$, Ruff CT, Giugliano RP, Murphy SA, Nordio F, Patel I, Shi M, Mercuri M, Antman EM, Braunwald E: Concomitant use of single antiplatelet therapy with edoxaban or warfarin in patients with atrial fibrillation: analysis from the ENGAGE AF-TIMI48 Trial. J Am Heart Assoc 2016;2016:e002587.

21 Fox KA, Piccini JP, Wojdyla D, Becker RC, Halperin JL, Nessel CC, Paolini JF, Hankey GJ, Mahaffey KW, Patel MR, Singer DE, Califf RM: Prevention of stroke and systemic embolism with rivaroxaban compared with warfarin in patients with non-valvular atrial fibrillation and moderate renal impairment. Eur Heart J 2011;32:2387-2394.

22 Fordyce CB, Hellkamp AS, Lokhnygina Y, Lindner SM, Piccini JP, Becker RC, Berkowitz SD, Breithardt G, Fox KA, Halperin JL, Hankey GJ, Mahaffey KW, Nessel CC, Singer DE, Patel MR: On-treatment outcomes in patients with worsening renal function with rivaroxaban compared with warfarin: insights from ROCKET AF. Circulation 2015;132:A16914.

23 Connolly SJ, Ezekowitz MD, Yusuf S, Reilly PA, Wallentin L; Randomized Evaluation of Long-Term Anticoagulation Therapy Investigators: newly identified events in the RE-LY trial. N Engl J Med 2010;363:1875-1876.

24 Douxfils J, Buckinx F, Mullier F, Minet V, Rabenda V, Reginster JY, Hainaut $P$, Bruyere $O$, Dogne JM: Dabigatran etexilate and risk of myocardial infarction, other cardiovascular events, major bleeding, and all-cause mortality: a systematic review and meta-analysis of randomized controlled trials. J Am Heart Assoc 2014;3:e000515.

25 Loffredo L, Perri L, Violi F: Myocardial infarction and atrial fibrillation: different impact of anti-IIa versus anti-Xa new oral anticoagulants: a meta-analysis of the interventional trials. Int J Cardiol 2015;178:8-9.
26 Hohnloser SH, Oldgren J, Yang S, Wallentin L, Ezekowitz M, Reilly P, Eikelboom J, Brueckmann M, Yusuf S, Connolly SJ: Myocardial ischemic events in patients with atrial fibrillation treated with dabigatran or warfarin in the RE-LY (Randomized Evaluation of Long-Term Anticoagulation Therapy) trial. Circulation 2012;125:669-676.

27 Di Cera E: Thrombin as procoagulant and anticoagulant. J Thromb Haemost 2007;5(suppl 1):196-202.

28 Alexander JH, Lopes RD, James S, Kilaru R, He Y, Mohan P, Bhatt DL, Goodman S, Verheugt FW, Flather M, Huber K, Liaw D, Husted SE, Lopez-Sendon J, De Caterina R, Jansky $\mathrm{P}$, Darius H, Vinereanu D, Cornel JH, Cools F, Atar D, Leiva-Pons JL, Keltai M, Ogawa H, Pais P, Parkhomenko A, Ruzyllo W, Diaz R, White H, Ruda M, Geraldes M, Lawrence J, Harrington RA, Wallentin L; APPRAISE Investigators: Apixaban with antiplatelet therapy after acute coronary syndrome. N Engl J Med 2011;365:699-708.

29 Oldgren J, Budaj A, Granger CB, Khder Y, Roberts J, Siegbahn A, Tijssen JG, Van de Werf F, Wallentin L; RE-DEEM Investigators: Dabigatran vs. placebo in patients with acute coronary syndromes on dual antiplatelet therapy: a randomized, double-blind, phase II trial. Eur Heart J 2011;32:2781-2789.

30 Mega JL, Braunwald E, Wiviott SD, Bassand JP, Bhatt DL, Bode C, Burton P, Cohen M, Cook-Bruns N, Fox KA, Goto S, Murphy SA, Plotnikov AN, Schneider D, Sun X, Verheugt FW, Gibson CM; ATLAS ACS TIMI Investigators: Rivaroxaban in patients with a recent acute coronary syndrome. N Engl J Med 2012; 366:9-19.

31 Krantz MJ, Kaul S: The ATLAS ACS 2-TIMI 51 trial and the burden of missing data: (AntiXa Therapy to Lower Cardiovascular Events in Addition to Standard Therapy in Subjects with Acute Coronary Syndrome ACS 2-Thrombolysis In Myocardial Infarction 51). J Am Coll Cardiol 2013;62:777-781.

32 Noseworthy PA, Kapa S, Deshmukh AJ, Madhavan M, Van Houten H, Haas LR, Mulpuru SK, McLeod CJ, Asirvatham SJ, Friedman PA, Shah ND, Packer DL: Risk of stroke after catheter ablation versus cardioversion for atrial fibrillation: a propensity-matched study of 24,244 patients. Heart Rhythm 2015;12:11541161 .

33 Nagarakanti R, Ezekowitz MD, Oldgren J, Yang S, Chernick M, Aikens TH, Flaker G, Brugada J, Kamensky G, Parekh A, Reilly PA, Yusuf S, Connolly SJ: Dabigatran versus warfarin in patients with atrial fibrillation: an analysis of patients undergoing cardioversion. Circulation 2011;123:131-136.
34 Piccini JP, Stevens SR, Lokhnygina Y, Patel MR, Halperin JL, Singer DE, Hankey GJ, Hacke W, Becker RC, Nessel CC, Mahaffey KW, Fox KA, Califf RM, Breithardt G; ROCKET AF Steering Committee Investigators: Outcomes after cardioversion and atrial fibrillation ablation in patients treated with rivaroxaban and warfarin in the ROCKET AF trial. J Am Coll Cardiol 2013;61:1998-2006.

35 Flaker G, Lopes RD, Al-Khatib SM, Hermosillo AG, Hohnloser SH, Tinga B, Zhu J, Mohan P, Garcia D, Bartunek J, Vinereanu D, Husted S, Harjola VP, Rosenqvist M, Alexander JH, Granger CB: Efficacy and safety of apixaban in patients after cardioversion for atrial fibrillation: insights from the ARISTOTLE Trial (Apixaban for Reduction in Stroke and Other Thromboembolic Events in Atrial Fibrillation). J Am Coll Cardiol 2014; 63:1082-1087.

36 Dentali F, Botto GL, Gianni M, Ambrosino P, Di Minno MN: Efficacy and safety of direct oral anticoagulants in patients undergoing cardioversion for atrial fibrillation: a systematic review and meta-analysis of the literature. Int J Cardiol 2015;185:72-77.

37 Lip GY, Merino J, Ezekowitz M, Ellenbogen $\mathrm{K}$, Zamoryakhin D, Lanz H, Jin J, Al-Saadi N, Mercuri M, Goette A: A prospective evaluation of edoxaban compared to warfarin in subjects undergoing cardioversion of atrial fibrillation: the EdoxabaN vs. warfarin in subjectS UndeRgoing cardiovErsion of Atrial Fibrillation (ENSURE-AF) study. Am Heart J 2015;169:597.e5-604.e5.

38 Cappato R, Ezekowitz MD, Klein AL, Camm AJ, Ma CS, Le Heuzey JY, Talajic M, Scanavacca $M$, Vardas $P E$, Kirchhof $P$, Hemmrich M, Lanius V, Meng IL, Wildgoose P, van Eickels $\mathrm{M}$, Hohnloser $\mathrm{SH}$; X-VeRT Investigators: Rivaroxaban vs. vitamin $\mathrm{K}$ antagonists for cardioversion in atrial fibrillation. Eur Heart J 2014;35:3346-3355.

39 Pallisgaard JL, Lindhardt TB, Hansen ML, Schjerning AM, Olesen JB, Staerk L, TorpPedersen C, Gislason GH: Cardioversion and risk of adverse events with dabigatran versus warfarin - a nationwide cohort study. PLoS One 2015;10:e0141377.

40 Diener HC, Connolly SJ, Ezekowitz MD, Wallentin L, Reilly PA, Yang S, Xavier D, Di Pasquale G, Yusuf S; RE-LY Study Group: Dabigatran compared with warfarin in patients with atrial fibrillation and previous transient ischaemic attack or stroke: a subgroup analysis of the RE-LY trial. Lancet Neurol 2010;9:1157-1163.

41 Easton JD, Lopes RD, Bahit MC, Wojdyla DM, Granger CB, Wallentin L, Alings $M$, Goto S, Lewis BS, Rosenqvist M, Hanna M, Mohan P, Alexander JH, Diener HC; ARISTOTLE Committees Investigators: Apixaban compared with warfarin in patients with atrial fibrillation and previous stroke or transient ischaemic attack: a subgroup analysis of the ARISTOTLE trial. Lancet Neurol 2012;11: 503-511. 
42 Hankey GJ, Patel MR, Stevens SR, Becker RC, Breithardt G, Carolei A, Diener HC, Donnan GA, Halperin JL, Mahaffey KW, Mas JL, Massaro A, Norrving B, Nessel CC, Paolini JF, Roine RO, Singer DE, Wong L, Califf RM, Fox KA, Hacke W: Rivaroxaban compared with warfarin in patients with atrial fibrillation and previous stroke or transient ischaemic attack: a subgroup analysis of ROCKET AF. Lancet Neurol 2012;11:315-322.

43 Sardar P, Chatterjee S, Wu WC, Lichstein E, Ghosh J, Aikat S, Mukherjee D: New oral anticoagulants are not superior to warfarin in secondary prevention of stroke or transient ischemic attacks, but lower the risk of intracranial bleeding: insights from a meta-analysis and indirect treatment comparisons. PLoS One 2013;8:e77694.

44 Eikelboom JW, Connolly SJ, Brueckmann M, Granger CB, Kappetein AP, Mack MJ, Blatchford J, Devenny K, Friedman J, Guiver K, Harper R, Khder Y, Lobmeyer MT, Maas H, Voigt JU, Simoons ML, Van de Werf F; REALIGN Investigators: Dabigatran versus warfarin in patients with mechanical heart valves. N Engl J Med 2013;369:1206-1214.
45 Yadlapati A, Groh C, Malaisrie SC, Gajjar M, Kruse J, Meyers S, Passman R: Efficacy and safety of novel oral anticoagulants in patients with bioprosthetic valves. Clin Res Cardiol 2016;105:268-272.

46 Avezum A, Lopes RD, Schulte PJ, Lanas F, Gersh BJ, Hanna M, Pais P, Erol C, Diaz R, Bahit MC, Bartunek J, De Caterina R, Goto S, Ruzyllo W, Zhu J, Granger CB, Alexander JH: Apixaban in comparison with warfarin in patients with atrial fibrillation and valvular heart disease: findings from the apixaban for reduction in stroke and other thromboembolic events in atrial fibrillation (ARISTOTLE) trial. Circulation 2015;132:624-632.

47 PRAXBIND ${ }^{\circledR}$ : PRAXBIND $^{\circledR}$ (idarucizumab) injection, for intravenous use. Full prescribing information. http://www.accessdata.fda. gov/drugsatfda_docs/label/2015/761025lbl. pdf (accessed February 12, 2016). Ridgefield, Boehringer Ingelheim Pharmaceuticals, 2015.

48 Pollack CV Jr, Reilly PA, Eikelboom J, Glund S, Verhamme P, Bernstein RA, Dubiel R, Huisman MV, Hylek EM, Kamphuisen PW, Kreuzer J, Levy JH, Sellke FW, Stangier J, Steiner T, Wang B, Kam CW, Weitz JI: Idarucizumab for dabigatran reversal. N Engl J Med 2015;373:511-520.
49 Levy JH, Ageno W, Chan NC, Crowther M, Verhamme P, Weitz JI: When and how to use antidotes for the reversal of direct oral anticoagulants: guidance from the SSC of the ISTH. J Thromb Haemost 2016;14:623-627.

50 Siegal DM, Curnutte JT, Connolly SJ, Lu G, Conley PB, Wiens BL, Mathur VS, Castillo J, Bronson MD, Leeds JM, Mar FA, Gold A, Crowther MA: Andexanet alfa for the reversal of factor Xa inhibitor activity. N Engl J Med 2015;373:2413-2424.

51 Crowther M, Levy GG, Lu G, Leeds J, Lin J, Pratikhya P, Conley PB, Connolly S, Curnutte JT: A phase 2 randomized, double-blind, placebocontrolled trial demonstrating reversal of edoxaban-induced anticoagulation in healthy subjects by andexanet alfa (PRT064445), a universal antidote for factor Xa (fXa) inhibitors. Blood 2014; 124:4269.

52 Portola Pharmaceuticals completes BLA submission to U.S. Food and Drug Administration for andexanet alfa. http://investors. portola.com/phoenix.zhtml?c=198136\&p= irol-newsArticle \&ID=2123971 (accessed February 12,2016 ). 